Article

\author{
MACIEL, C.D.G. ${ }^{1 *}$ \\ LUSTOSA, S.B.C. ${ }^{1}$ \\ HELVIG, E.O. ${ }^{1}$ \\ COSTA, A.G.F. ${ }^{2}$ \\ RIBEIRO, R.B. ${ }^{3}$ \\ MATIAS, J.P. ${ }^{4}$
}

\section{Selectivity of Chlorimuron-Ethyl to Castorbean CROPS}

\section{Seletividade de Chlorimuron-Ethyl para Cultura da Mamoneira}

\begin{abstract}
Castorbean presents high sensitivity to competition; therefore, it is necessary to develop alternatives for the weed management, mainly for the chemical control of eudicotyledons species. The goal of this work was to evaluate the selectivity of chlorimuron-ethyl to castorbean crops in different development stages. Four experiments differentiated by the genetic material were conducted: Lyra, Íris and Savana hybrids and AL Guarany 2002 cultivar. The treatments corresponded to the application conditions of chlorimuron-ethyl [sample control with no application, doses of 15 e $20 \mathrm{~g}$ a.i. ha ${ }^{-1}$ with the formulations Classic $^{\mathrm{TM}}$ and Clorimuron Master Nortox $\left.^{\mathrm{TM}}\right]$ in two phenological crop stages (4 to 5 and 7 to 8 true leaf stages). The experimental design was in randomized blocks with four replications, in a factorial scheme of $5 \times 2$ (herbicide and application stage). The intoxication was more severe for the 7 to 8 leaf stage and with the dose of $20 \mathrm{~g} \mathrm{ha}^{-1}$ on day 7 days after application (DAA); there were plant recovery and mild symptoms on day 21 DAA, especially for the 4 to 5 leaf stage. The yield was reduced with the $20 \mathrm{~g} \mathrm{ha}^{-1}$ dose for Lyra hybrid with both formulations and for Savana castorbean, only with the Classic ${ }^{\mathrm{TM}}$ formulation. The chlorimuron-ethyl herbicide, at $15 \mathrm{~g} \mathrm{ha}^{-1}$, showed selectivity to castorbean, regardless of the stage application (4 to 5 or 7 to 8 leaves).
\end{abstract}

Keywords: intoxication, formulation, dose, Ricinus communis L.

RESUMO - A mamoneira apresenta elevada sensibilidade à competição, sendo necessário desenvolver alternativas de manejo de plantas daninhas, principalmente para o controle químico de espécies eudicotiledôneas. Objetivou-se com este trabalho avaliar a seletividade do herbicida chlorimuron-ethyl à cultura da mamoneira em diferentes estádios de desenvolvimento. Foram conduzidos quatro experimentos distintos pelo material genético: os híbridos Lyra, Íris e Savana e o cultivar AL Guarany 2002. Os tratamentos corresponderam acondições da aplicação de chlorimuron-ethyl [testemunha sem aplicação, doses a $15 \mathrm{e}$ 20 g i.a. ha $a^{-1}$ com as formulações Classic ${ }^{\circledR}$ e Clorimuron Master Nortox $\left.{ }^{\circledR}\right]$ em dois estádios fenológicos da cultura (4 a 5 e 7 a 8 folhas verdadeiras). $O$ delineamento foi de blocos casualizados com quatro repetições, em esquema fatorial de $5 \times 2$ (herbicida e estádio de aplicação). A intoxicação foi mais severa para o estádio de 7 a 8 folhas e a dose de $20 \mathrm{~g} \mathrm{ha} a^{-1}$ aos 7 dias após aplicação (DAA), ocorrendo recuperação das plantas e sintomas leves aos 21 DAA, especialmente para o estádio de 4 a 5 folhas. A produtividade foi reduzida com a dose de $20 \mathrm{~g} \mathrm{ha-1}$ para o híbrido Lyra com ambas as formulações e para a mamoneira Savana somente com a formulação Classic ${ }^{\circledR}$. O herbicida chlorimuron-ethyl a $15 \mathrm{~g} \mathrm{ha}^{-1}$ se mostrou seletivo à mamoneira, independentemente do estádio de aplicação (4 a 5 ou 7 a 8 folhas).

Palavras-chave: intoxicação, formulação, dose, Ricinus communis L.

1 Universidade Estadual do Centro-Oeste, PPGA/UNICENTRO. Guarapuava-PR, Brasil; ${ }^{2}$ Embrapa Algodão, Campina GrandePB, Brasil; ${ }^{3}$ Escola Superior de Agronomia de Paraguaçu Paulista, Paraguaçu Paulista-SP, Brasil. ${ }^{4}$ Universidade Estadual de Maringá, PAG/UEM. Umuarama-PR, Brasil. 


\section{INTRODUCTION}

The castorbean (Ricinus communis L.) is a tropical species, whose oil, extracted from its seeds, is one of the most versatile, with innumerous industrial applications (Chagas et al., 2014). However, the world consumption has been limited by the low availability in the market (Severino et al., 2012), which demonstrates great economic potential to expand the cultivation of this oleaginous plant (Campbell et al., 2014).

In this scenario, Brazil is the world fourth biggest castorbean producer, and its participation corresponds to less than $2 \%$ of the total $(\mathrm{FAO}, 2016)$. The averages of production, cultivated area and productivity in the last five harvests were 55 thousand tons, 124 thousand hectares and $406 \mathrm{~kg} \mathrm{ha}^{-1}$; $93 \%$ of this production was concentrated in the northeastern region (Conab, 2016). However, considering that castorbean may produce more than $2,000 \mathrm{~kg}$ of seeds ha-1 (Soratto et al., 2011), the Brazilian productivity is considered extremely low, demanding the improvement of its production systems, in order to allow greater expansion of its cultivated area (Costa et al., 2015).

Starting from the launch of genetic materials that are smaller, more precocious and productive (Fioreze et al., 2016), as well as from the development of the mechanized harvest, the culture has been drawing the attention of producers as a possible cultivation option for higher technology level regions, especially in grain producing areas of the Brazilian Cerrado. Thus, one of the difficulties to obtain higher productivities and, at the same time, enable the cultivation of castorbean on a large scale is to expand the alternatives for the management of weeds.

The difficulty of using the mechanical control of weeds in the reduced spaces between the lines that are recommended for more recent cultivars or hybrids, as well as the respective cost involving workforce, has demanded the need to use chemical control more and more (Costa et al., 2014; Silva et al., 2015). However, it is important to highlight that there are no selective products registered at the Ministry of Agriculture, Livestock, and Supply - MAPA (Brazil, 2016a).

In the previous studies, it has been verified that there are selective herbicide for castorbean with a predominant control spectrum over monocots from the Poaceae family, such as pendimethalin, trifluralin and clomazone in applications performed during pre-emergence, in spite of having an action over some eudicot species. Another option to control graminaceous species in post-emergence is the use of herbicides that are ACCase inhibitors, such as fluazifopp-butyl, sethoxydim, haloxyfop-methyl, quizalofop-p-ethyl, clethodim, clethodim + fenoxaprop-pethyl, propaquizafop and butroxydim (Maciel et al., 2007, 2011, 2012; Silva et al., 2012; Grichar et al., 2012; Medeiros et al., 2013).

In order to expand the options to manage eudicots, studies with herbicide associations in pre- (PRE) and post-emergence (POST) have indicated chorimuron-ethyl as the main option to control "large leaves" in the castorbean culture. Sofiatti et al. (2012) verified that the management of weeds in pre-emergence with trifluralin, pendimethalin or clomazone associated to the application in post-emergence of chlorimuron-ethyl provided satisfactory control of Walteria indica, without causing injuries to the culture. Similarly, Costa et al. (2015) noticed satisfactory control of Richardia scabra with s-metolachlor + clomazone applied in pre-emergence, combined with the sequential application of chlorimuron-ethyl and halosulfuron-methyl in post-emergence. In both works, these treatments provided similar productivity to the one from the harvested control sample.

Therefore, in order to expand results and information that allow greater knowledge about the castorbean tolerance to chlorimuron-ethyl, new studies on the field are necessary; they must be specific for the evaluation of selectivity, considering the factors related to dose, formulation and moment of application of the herbicide on different hybrids or cultivars. Thus, starting from experiments with different genetic materials, the goal of this work was to evaluate the selectivity of the chlorimuron-ethyl herbicide to the castorbean culture in different development stages.

\section{MATERIAL AND METHODS}

The work was conducted in the city of Paraguaçu Paulista - São Paulo state, at the coordinates of $22^{\circ} 24^{\prime} 46^{\prime \prime} \mathrm{S}$ and $50^{\circ} 34^{\prime} 33^{\prime \prime} \mathrm{W}$, at an average altitude of $480 \mathrm{~m}$. The climate of the region, 
according to Köppen, is Aw type, characterized by savannah with dry winters. The average annual temperature of the region is $22.8{ }^{\circ} \mathrm{C}$, with amplitude of $5{ }^{\circ} \mathrm{C}$; the average annual rainfall is $1,361 \mathrm{~mm}$, with rainy seasons from December to February and dry ones from June to August.

The soil of the experimental area was classified as dystrophic Red Latosol (Embrapa, 2013); it was constituted by $83 \%$ sand, $5 \%$ silt and $12 \%$ clay. The chemical characteristics that were sampled before installing the tests for the $0-20 \mathrm{~cm}$ layer were: $\mathrm{pH}$ in water $=5.8$; $\mathrm{Ca}^{+2}=12 \mathrm{mmol}_{\mathrm{c}} \mathrm{dm}^{-3} ; \mathrm{Mg}=5 \mathrm{mmol}_{\mathrm{c}} \mathrm{dm}^{-3} ; \mathrm{H}^{+}+\mathrm{Al}^{+3}=9 \mathrm{mmol}_{\mathrm{c}} \mathrm{dm}^{-3} ; \mathrm{CTC}=29 \mathrm{mmol}_{\mathrm{c}} \mathrm{dm}^{-3} ; \mathrm{V} \%=69 ;$ $\mathrm{Al}^{+3}=0 \mathrm{mmol}_{\mathrm{c}} \mathrm{dm}^{-3} ; \mathrm{P}=20 \mathrm{mg} \mathrm{dm}^{-3} ; \mathrm{K}^{+}=2.9 \mathrm{mmol}_{\mathrm{c}} \mathrm{dm}^{-3} ;$ and $\mathrm{MO}=10 \mathrm{~g} \mathrm{dm}^{-3}$.

Four distinct experiments were performed, using as genetic materials the castorbean hybrids Lyra, Iris and Savana and the AL Guarany 2002 cultivar. Cultivar is defined as the variety of any vegetal genus or species that is clearly distinguishable from other cultivars, and that is homogeneous and stable as for the descriptors through the following generations. Hybrid is the immediate product of the crossbreeding between genetically different lineages (Brazil, 2016b). Historically, in spite of the predominance in launching castorbean cultivars in Brazil, over the last few years there has been greater demand for hybrids that are meant for the mechanized harvest, mainly for the cerrado area, which is a region currently considered of great potential to expand the culture.

Seeding was performed manually, with four seeds per hole, at $3 \mathrm{~cm}$ depth. There was a space of $0.5 \mathrm{~m}$ between the plants and $1 \mathrm{~m}$ between the rows $(0.5 \times 1 \mathrm{~m})$ for the hybrids and $1 \times 1 \mathrm{~m}$ for the cultivar. Staring from the stabilization of the emergence, thinning was performed 20 days after seeding (DAS), leaving one plant per hole. Base fertilizing was performed with $300 \mathrm{~kg} \mathrm{ha}^{-1}$ of the 04-14-08 formula and the covering with $160 \mathrm{~kg} \mathrm{ha}^{-1}$ of ammonium sulphate, on day 30 after the emergence (DAE) of the culture.

The used experimental design was the randomized blocks one, with ten treatments and four replications, organized in $5 \times 2$ factor scheme. Factor A, represented by five treatments, was constituted by doses of 15 and $20 \mathrm{~g} \mathrm{ha}^{-1}$ chlorimuron-ethyl in the A (Classic ${ }^{\mathrm{TM}}$ ) and $\mathrm{B}$ (Clorimuron Master Nortox $^{\mathrm{TM}}$ ) formulations, respectively corresponding to 60 and 80 g p.c. ha ${ }^{-1}$, as well as a control sample with no application. Two commercial products were used to expand the data base of this study, mainly considering probable differences between the substances used to compose the portion of inert ingredients from these formulations that may interfere in the action of the evaluated herbicide. Factor B corresponded to two development stages of the castorbean to apply the herbicide: 4 to 5 and 7 to 8 true leaves. In all application solution, mineral oil was added (756 $\mathrm{g} \mathrm{L}^{-1}$ of aliphatic hydrocarbon) at $0.5 \%\left(\mathrm{v} \mathrm{v}^{-1}\right)$.

The experimental units were constituted by $3 \mathrm{~m}$ wide and $4 \mathrm{~m}$ long plots that were kept weeded during the whole experimental period, in order to eliminate the effect of the interference caused by weeds on the culture, leaving the castorbean only exposed to the action of the evaluated herbicides. As a border, a seeding row on each side was considered, in the longitudinal direction, and $0.5 \mathrm{~m}$ of the other edges; they consisted in the dimensions of the plots' usable area.

For all genetic materials, chlorimuron-ethyl applications were performed on day 25 and 44 DAS for the stage from 4 to 5 and 7 to 8 leaves, respectively. $\mathrm{A} \mathrm{CO}_{2}$ pressurized backpack sprayer was used, equipped with four XR11002 VP flat spray nozzles, spaced $0.5 \mathrm{~m}$ apart, and placed at $0.5 \mathrm{~m}$ from the soil surface, with working pressure of $210 \mathrm{KPa}$ and mixture consumption of $200 \mathrm{~L} \mathrm{ha}^{-1}$. During the applications of treatments from the first and second phenological stages of castorbean, the conditions of wind speed, temperature and relative air humidity corresponded, on an average, to: 1.3 and $2.3 \mathrm{~km} \mathrm{~h}^{-1} ; 24.6$ and $31{ }^{\mathrm{E} \%} \mathrm{C}$ and 69 ; and $76 \%$.

Intoxication evaluations were performed on day 7, 14 and 21 after application (DAA), by visual grades, where $0 \%$ corresponded to the absence of injuries and $100 \%$ to plant death, according to SBCPD (1995). Chlorophyll content was evaluated on day 7 DAA, by a Minolta ${ }^{\circledR}$ manual chlorophyll meter (SPAD index). The height of plants $(\mathrm{cm})$ and the diameter of the stem $(\mathrm{mm})$ were obtained on day 40 after the second application; the height was measured from the soil surface to the primary raceme edge, and the stem diameter was obtained at $15 \mathrm{~cm}$ from the soil surface. Productivity $\left(\mathrm{kg} \mathrm{ha}^{-1}\right)$ was evaluated at the end of the experimental period (140 DAE), by weighing castorbean grains harvested in the usable area of the plot. 
The obtained data were submitted to analysis of variance by $\mathrm{F}$ test and the averages were compared by Tukey's test at $5 \%$ probability.

\section{RESULTS AND DISCUSSION}

Visual intoxication symptoms were provided by chlorimuron-ethyl on the evaluated castorbean hybrids and cultivars; there was an effect of the herbicide treatments and respective castorbean stages at the time of the application (Tables 1 and 2).

Considering the averages obtained starting from all genetic materials and herbicide treatments on day 7, 14 and 21 DAA, values for the application with 4 to 5 leaves corresponded to 36,9 and $3 \%$ and, for the 7 to 8 leaves stage, to 54, 23 and $11 \%$, respectively. Generally speaking, it was noticed that the highest percentages were caused by applications in the latest stage of castorbean (7 to 8 true leaves); it was also possible to verify that the symptoms were more severe on day 7 DAA, with a decrease in the following evaluations, indication the recovery of plants. However, on day 21 DAA, for applications with 7 to 8 leaves in the Savana hybrid, symptoms

Table 1 - Intoxication of castorbeans Lyra and Isis on day 7, 14 and 21 DAA by chlorimuron-ethyl in post-emergence

\begin{tabular}{|c|c|c|c|c|c|c|}
\hline \multirow{3}{*}{ Treatments } & \multicolumn{6}{|c|}{ Intoxication (\%) of Lyra castorbean } \\
\hline & \multicolumn{2}{|c|}{$7 \mathrm{DAA}$} & \multicolumn{2}{|c|}{$14 \mathrm{DAA}$} & \multicolumn{2}{|c|}{$21 \mathrm{DAA}$} \\
\hline & 4-5 leaves & 7-8 leaves & 4-5 leaves & 7-8 leaves & 4-5 leaves & 7-8 leaves \\
\hline Control sample & $0.0 \mathrm{c} \mathrm{A}$ & $0.0 \mathrm{c} \mathrm{A}$ & $0.0 \mathrm{~b} \mathrm{~A}$ & $0.0 \mathrm{c} \mathrm{A}$ & $0.0 \mathrm{~b} \mathrm{~A}$ & $0.0 \mathrm{c} \mathrm{A}$ \\
\hline $\begin{array}{l}\text { Formulation A } \\
\left(15 \mathrm{~g} \text { a.i. } \mathrm{ha}^{-1}\right)\end{array}$ & $47.5 \mathrm{~b} \mathrm{~B}$ & $61.3 \mathrm{~b} \mathrm{~A}$ & 15.8 a B & $29.3 \mathrm{~b} \mathrm{~A}$ & $3.5 \mathrm{ab} B$ & $7.8 \mathrm{~b} \mathrm{~A}$ \\
\hline $\begin{array}{l}\text { Formulation B } \\
\left(15 \mathrm{~g} \text { a.i. } \mathrm{ha}^{-1}\right)\end{array}$ & $47.0 \mathrm{~b} \mathrm{~B}$ & $65.0 \mathrm{~b} \mathrm{~A}$ & 15.8 a B & $32.0 \mathrm{ab} \mathrm{A}$ & $3.0 \mathrm{ab} \mathrm{B}$ & $9.3 \mathrm{ab} \mathrm{A}$ \\
\hline $\begin{array}{l}\text { Formulation A } \\
\left(20 \mathrm{~g} \text { a.i. } \mathrm{ha}^{-1}\right)\end{array}$ & $57.0 \mathrm{ab} \mathrm{B}$ & 73.8 a $\mathrm{A}$ & 19.3 a B & $35.0 \mathrm{ab} \mathrm{A}$ & 7.8 a B & $13.0 \mathrm{a} \mathrm{A}$ \\
\hline $\begin{array}{l}\text { Formulation B } \\
\left(20 \mathrm{~g} \text { a.i. } \mathrm{ha}^{-1}\right)\end{array}$ & 53.3 a B & 75.3 a $\mathrm{A}$ & 19.5 a B & 37.8 a $\mathrm{A}$ & 6.3 a B & 13.5 a A \\
\hline $\mathrm{F}_{\text {cal }}$ Herbicides $(\mathrm{H})$ & \multicolumn{2}{|c|}{$371.31 *$} & \multicolumn{2}{|c|}{$70.50^{*}$} & \multicolumn{2}{|c|}{$25.29^{*}$} \\
\hline $\mathrm{F}_{\text {cal }}$ Stages $(\mathrm{S})$ & \multicolumn{2}{|c|}{$124.08 *$} & \multicolumn{2}{|c|}{$105.04^{*}$} & \multicolumn{2}{|c|}{$38.50^{*}$} \\
\hline $\mathrm{F}_{\text {cal }} \mathrm{H} \times \mathrm{E}$ & \multicolumn{2}{|c|}{$8.85^{*}$} & \multicolumn{2}{|c|}{$6.93^{*}$} & \multicolumn{2}{|c|}{$2.87^{\mathrm{NS}}$} \\
\hline VC $(\%)$ & \multicolumn{2}{|c|}{8.34} & \multicolumn{2}{|c|}{19.26} & \multicolumn{2}{|c|}{36.63} \\
\hline DMS H & \multicolumn{2}{|c|}{8.27} & \multicolumn{2}{|c|}{8.13} & \multicolumn{2}{|c|}{4.84} \\
\hline \multirow[t]{2}{*}{ DMS E } & \multicolumn{2}{|c|}{5.81} & \multicolumn{2}{|c|}{5.71} & \multicolumn{2}{|c|}{3.40} \\
\hline & \multicolumn{6}{|c|}{ Intoxication $(\%)$ of Iris castorbean } \\
\hline Control sample & $0.0 \mathrm{~b} \mathrm{~A}$ & $0.0 \mathrm{dA}$ & $0.0 \mathrm{c} \mathrm{A}$ & $0.0 \mathrm{~d} \mathrm{~A}$ & $0.0 \mathrm{~b} \mathrm{~A}$ & $0.0 \mathrm{~d} A$ \\
\hline $\begin{array}{l}\text { Formulation A } \\
\left(15 \mathrm{~g} \text { a.i. } \mathrm{ha}^{-1}\right)\end{array}$ & 31.8 a $\mathrm{A}$ & $38.8 \mathrm{c} \mathrm{A}$ & $6.5 \mathrm{~b} \mathrm{~B}$ & $11.5 \mathrm{c} \mathrm{A}$ & 3.0 a $\mathrm{A}$ & $3.0 \mathrm{c} \mathrm{A}$ \\
\hline $\begin{array}{l}\text { Formulation B } \\
\left(15 \mathrm{~g} \text { a.i. } \mathrm{ha}^{-1}\right)\end{array}$ & 32.5 a B & $43.8 \mathrm{bc} \mathrm{A}$ & $5.5 \mathrm{~b} \mathrm{~B}$ & $13.3 \mathrm{bc} \mathrm{A}$ & 3.0 a B & $5.5 \mathrm{~b} \mathrm{~A}$ \\
\hline $\begin{array}{l}\text { Formulation A } \\
\left(20 \mathrm{~g}_{\text {a.i. }} \mathrm{ha}^{-1}\right)\end{array}$ & 38.3 a B & $51.3 \mathrm{ab} \mathrm{A}$ & 9.3 a B & $15.3 \mathrm{ab} \mathrm{A}$ & $5.0 \mathrm{a} \mathrm{A}$ & $6.3 \mathrm{~b} \mathrm{~A}$ \\
\hline $\begin{array}{l}\text { Formulation B } \\
\left(20 \mathrm{~g}^{2} . \mathrm{i}^{-1} \mathrm{ha}^{-1}\right)\end{array}$ & 37.8 a B & 60.0 a $\mathrm{A}$ & $7.8 \mathrm{ab} B$ & 17.0 a $\mathrm{A}$ & 4.0 a B & 9.8 a A \\
\hline $\mathrm{F}_{\text {cal }}$ Herbicides $(\mathrm{H})$ & \multicolumn{2}{|c|}{$120.72 *$} & \multicolumn{2}{|c|}{$122.75^{*}$} & \multicolumn{2}{|c|}{$48.70^{*}$} \\
\hline $\mathrm{F}_{\text {cal }}$ Stages $(\mathrm{S})$ & \multicolumn{2}{|c|}{$45.78^{*}$} & \multicolumn{2}{|c|}{$188.16^{*}$} & \multicolumn{2}{|c|}{$31.44 *$} \\
\hline $\mathrm{F}_{\text {cal }} \mathrm{H} \times \mathrm{E}$ & \multicolumn{2}{|c|}{$5.34 *$} & \multicolumn{2}{|c|}{$14.95^{*}$} & & $4 *$ \\
\hline $\mathrm{VC}(\%)$ & & & & & & \\
\hline DMS H & & & & & & \\
\hline DMS E & & & & & & \\
\hline
\end{tabular}

Averages followed by the same lowercase letter in the column and the same capital letter on the line (within each evaluation period and genetic material) do not different among themselves by Tukey's test $(\mathrm{p} \leq 0.05)$. * significant by $\mathrm{F}$ test $(\mathrm{p} \leq 0.05)$; ${ }^{\text {ns }}=$ non significant. 
Table 2 - Intoxication of castorbeans Savana and AL Guarany 2002 on day 7, 14 and 21 DAA by chlorimuron-ethyl in post-emergence

\begin{tabular}{|c|c|c|c|c|c|c|}
\hline \multirow{3}{*}{ Treatments } & \multicolumn{6}{|c|}{ Intoxication (\%) of Savana castorbean } \\
\hline & \multicolumn{2}{|c|}{$7 \mathrm{DAA}$} & \multicolumn{2}{|c|}{$14 \mathrm{DAA}$} & \multicolumn{2}{|c|}{$21 \mathrm{DAA}$} \\
\hline & 4-5 leaves & 7-8 leaves & 4-5 leaves & 7-8 leaves & 4-5 leaves & 7-8 leaves \\
\hline Control sample & $0.0 \mathrm{~b} \mathrm{~A}$ & $0.0 \mathrm{~d} \mathrm{~A}$ & $0.0 \mathrm{~b} \mathrm{~A}$ & $0.0 \mathrm{c} \mathrm{A}$ & $0.0 \mathrm{a} \mathrm{A}$ & $0.0 \mathrm{~b} \mathrm{~A}$ \\
\hline $\begin{array}{l}\text { Formulation A } \\
\left(15 \mathrm{~g} \text { a.i. } \mathrm{ha}^{-1}\right)\end{array}$ & 33.8 a B & $55.0 \mathrm{bc} \mathrm{A}$ & 8.0 a B & $25.8 \mathrm{~b} \mathrm{~A}$ & $1.5 \mathrm{a} \mathrm{B}$ & 20.8 a A \\
\hline $\begin{array}{l}\text { Formulation B } \\
\left(15 \mathrm{~g} \text { a.i. } \mathrm{ha}^{-1}\right)\end{array}$ & 34.5 a B & $50.0 \mathrm{c} \mathrm{A}$ & $5.5 \mathrm{ab} \mathrm{B}$ & $25.8 \mathrm{~b} \mathrm{~A}$ & 0.8 a B & 20.0 a A \\
\hline $\begin{array}{l}\text { Formulation A } \\
\left(20 \mathrm{~g} \mathrm{a.i.}^{-1}\right)\end{array}$ & 36.3 a B & 68.8 a A & 7.5 a B & $31.5 \mathrm{ab} \mathrm{A}$ & $3.0 \mathrm{a} \mathrm{B}$ & 24.5 a A \\
\hline $\begin{array}{l}\text { Formulation B } \\
\left(20 \mathrm{~g} \mathrm{a.i.}^{-1}\right)\end{array}$ & 37.5 a B & $61.3 \mathrm{ab} \mathrm{A}$ & $6.5 \mathrm{ab} \mathrm{B}$ & 34.3 a $\mathrm{A}$ & $3.0 \mathrm{a} \mathrm{B}$ & 23.8 a A \\
\hline $\mathrm{F}_{\text {cal }}$ Herbicides $(\mathrm{H})$ & \multicolumn{2}{|c|}{$139.23^{*}$} & \multicolumn{2}{|c|}{$45.64^{*}$} & \multicolumn{2}{|c|}{$51.13^{*}$} \\
\hline $\mathrm{F}_{\text {cal }}$ Stages $(\mathrm{S})$ & \multicolumn{2}{|c|}{$130.75 *$} & \multicolumn{2}{|c|}{$265.73 *$} & \multicolumn{2}{|c|}{$527.21 *$} \\
\hline $\mathrm{F}_{\text {cal }} \mathrm{H} \times \mathrm{E}$ & \multicolumn{2}{|c|}{$11.00^{*}$} & \multicolumn{2}{|c|}{$18.98^{*}$} & \multicolumn{2}{|c|}{$33.33^{*}$} \\
\hline $\mathrm{VC}(\%)$ & \multicolumn{2}{|c|}{13.64} & \multicolumn{2}{|c|}{24.06} & \multicolumn{2}{|c|}{22.87} \\
\hline DMS H & \multicolumn{2}{|c|}{10.63} & \multicolumn{2}{|c|}{7.19} & \multicolumn{2}{|c|}{4.59} \\
\hline \multirow[t]{2}{*}{ DMS E } & \multicolumn{2}{|c|}{7.46} & \multicolumn{2}{|c|}{5.05} & \multicolumn{2}{|c|}{3.22} \\
\hline & \multicolumn{6}{|c|}{ Intoxication (\%) of the AL Guarany 2002 castorbean } \\
\hline Control sample & $0.0 \mathrm{~b} \mathrm{~A}$ & $0.0 \mathrm{~b} \mathrm{~A}$ & $0.0 \mathrm{~b} \mathrm{~A}$ & $0.0 \mathrm{c} \mathrm{A}$ & $0.0 \mathrm{a} \mathrm{A}$ & $0.0 \mathrm{c} \mathrm{A}$ \\
\hline $\begin{array}{l}\text { Formulation A } \\
\left(15 \mathrm{~g}^{2} \text { a.i. } \mathrm{ha}^{-1}\right)\end{array}$ & 18.8 a B & 36.3 a $\mathrm{A}$ & 2.3 a B & $13.5 \mathrm{~b} \mathrm{~A}$ & $0.0 \mathrm{a} \mathrm{B}$ & $2.8 \mathrm{~b} \mathrm{~A}$ \\
\hline $\begin{array}{l}\text { Formulation B } \\
\left(15 \mathrm{~g} \text { a.i. } \mathrm{ha}^{-1}\right)\end{array}$ & $19.5 \mathrm{aB}$ & 40.0 a A & 3.5 a B & $13.8 \mathrm{~b} \mathrm{~A}$ & $0.0 \mathrm{a} \mathrm{B}$ & $3.0 \mathrm{~b} \mathrm{~A}$ \\
\hline $\begin{array}{l}\text { Formulation A } \\
\left(20 \mathrm{~g} \mathrm{a.i.}^{-1}\right)\end{array}$ & 24.8 a B & 41.3 a $\mathrm{A}$ & 2.3 a B & $15.0 \mathrm{ab} \mathrm{A}$ & 0.0 a B & $5.5 \mathrm{a} \mathrm{A}$ \\
\hline $\begin{array}{l}\text { Formulation B } \\
\left(20 \mathrm{~g}^{\mathrm{a} . i .} \mathrm{ha}^{-1}\right)\end{array}$ & 25.3 a B & 46.3 a $\mathrm{A}$ & $4.0 \mathrm{a} \mathrm{B}$ & $16.3 \mathrm{a} \mathrm{A}$ & $0.0 \mathrm{a} \mathrm{B}$ & $5.5 \mathrm{a} \mathrm{A}$ \\
\hline $\mathrm{F}_{\text {cal }}$ Herbicides $(\mathrm{H})$ & \multicolumn{2}{|c|}{$59.04 *$} & \multicolumn{2}{|c|}{$113.24 *$} & \multicolumn{2}{|c|}{$46.56^{*}$} \\
\hline $\mathrm{F}_{\text {cal }}$ Stages $(\mathrm{S})$ & \multicolumn{2}{|c|}{$80.78^{*}$} & \multicolumn{2}{|c|}{$755.74 *$} & \multicolumn{2}{|c|}{$498.78^{*}$} \\
\hline $\mathrm{F}_{\text {cal }} \mathrm{H} \times \mathrm{E}$ & \multicolumn{2}{|c|}{$5.31^{*}$} & \multicolumn{2}{|c|}{$48.85^{*}$} & & $6^{*}$ \\
\hline $\mathrm{VC}(\%)$ & & & & & & \\
\hline DMS H & & & & & & \\
\hline DMS E & & & & & & \\
\hline
\end{tabular}

Averages followed by the same lowercase letter in the column and the same capital letter on the line (within each evaluation period and genetic material) do not different among themselves by Tukey's test $(\mathrm{p} \leq 0.05)$. ${ }^{*}$ significant by $\mathrm{F}$ test $(\mathrm{p} \leq 0.05)$; ${ }^{\text {ns }}=$ non significant.

remained between 20 and 25\%, regardless of the dose or formulation of the herbicide. For cultivar AL Guarany 2002, there was no intoxication symptom on day 21 DAA for the applications performed on plants with 4 to 5 true leaves. As for the hybrids, light to very light symptoms occurred for this same stage, with percentages between 1 and 8\%, which may be considered acceptable.

Similarly, Sofiatti et al. (2012) did not observe visual intoxication on day 20 and 40 DAA from chlorimuron-ethyl $\left(15 \mathrm{~g} \mathrm{ha}^{-1}\right)$ on castorbean plants submitted to the application with 2 to 6 true leaves. Costa et al. (2015) verified just a slight intoxication on day 7 and 15 from the sequential application of chlorimuron-ethyl (15 $\left.\mathrm{g} \mathrm{ha}^{-1}\right)$ and halosulfuron-methyl (112.5 $\left.\mathrm{g} \mathrm{ha}^{-1}\right)$ on the stage of 4 to 6 true leaves, with later recovery and absence of symptoms on day 23 DAA. In both works, chlorimuron-ethyl was used for weed management control; it was associated to herbicide application in pre-emergence, with predominant effect over monocots (pendimethalin, trifluralin, clomazone and s-metolachlor).

Generally speaking, representative symptoms of chlorimuron-ethyl intoxication observed on day 14 DAA were characterized by chlorosis among the veins, mainly of new leaves, developing 
a mosaic format (irregular stains), followed by the wrinkling of the foliar limb, with downward facing edges (Figures 1 and 2). Under conditions of more accentuated injury symptoms, it was also possible to observe the compaction of foliar limbs and petioles. Hijano et al. (2013) reported that the action mechanism of chlorimuron-ethyl inhibits the acetolactate synthase enzyme (ALS), blocking the synthesis of amino acids of the aliphatic lateral chain, such as valine, leucine and isoleucine. ALS enzyme inhibitors are characterized as systemic and may accumulate in the apical meristem, damaging the growth and development of sensitive plants.

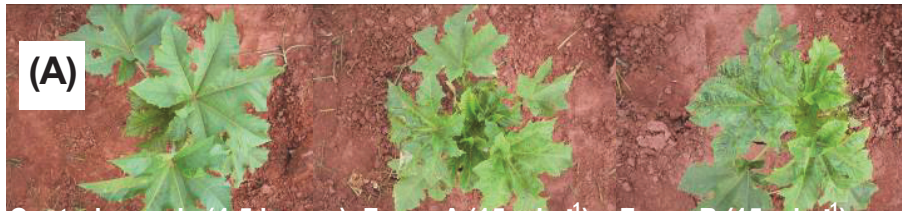

Control sample (4-5 leaves) Form. A (15 $\left.g h^{-1}\right)$ Form. B (15 g há $)$
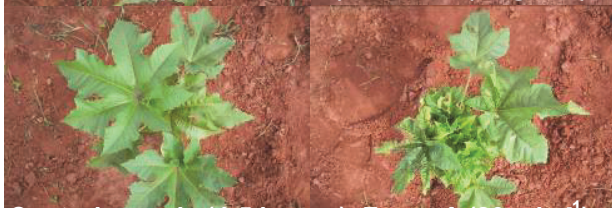

Control sample (4-5 leaves) Form. A $\left(20 \mathrm{~g} \mathrm{ha}^{-1}\right)$
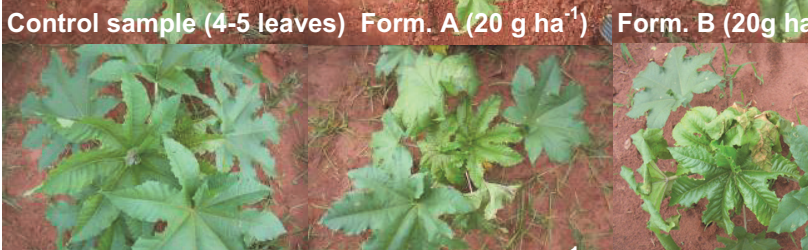

Control sample (7-8 leaves) form. A $\left(15 \mathrm{~g} \mathrm{ha}^{-1}\right)$ Form. B $\left(15 \mathrm{~g} \mathrm{ha}^{-1}\right)$

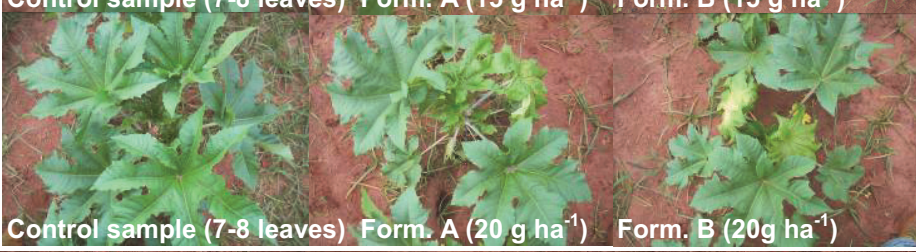

\section{(B)}
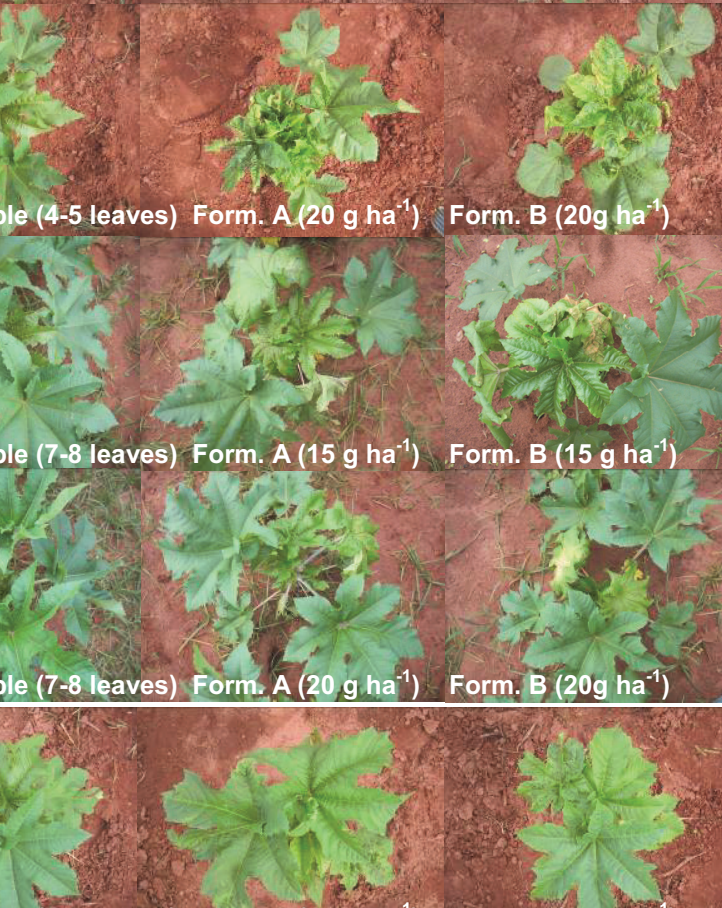

Control sample (4-5 leaves) Form. A (15 $\left.\mathrm{g} \mathrm{ha}^{-1}\right)$ Form. B (15 g ha-1)
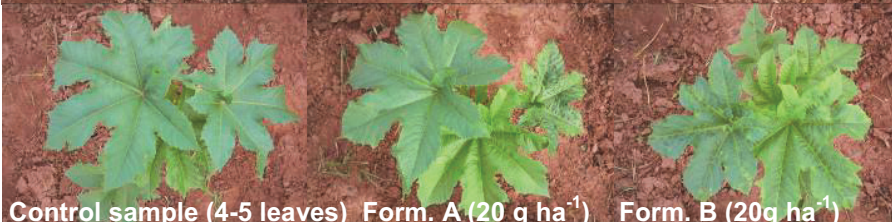

Control sample (4-5 leaves) Form. A $\left(20 \mathrm{~g} \mathrm{ha}^{-1}\right)$ Form. B $\left(20 \mathrm{~g} \mathrm{ha}^{-1}\right)$ )
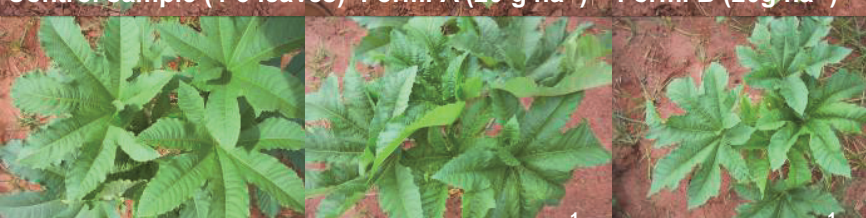

Control sample (7-8 leaves) Form. A (15 $\mathrm{g} \mathrm{ha}^{-1}$ ) Form. B (15 g hä)

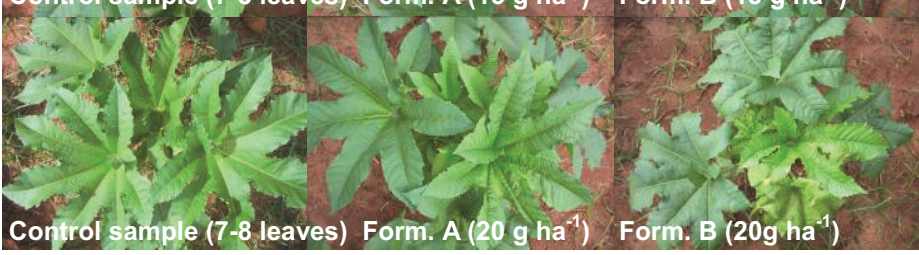

Figure 1 - Visual symptoms of intoxication on day 14 DAA on the hybrids Lyra (A) and Iris (B) submitted to the application in post-emergence of chlorimuron-ethyl in different stages.

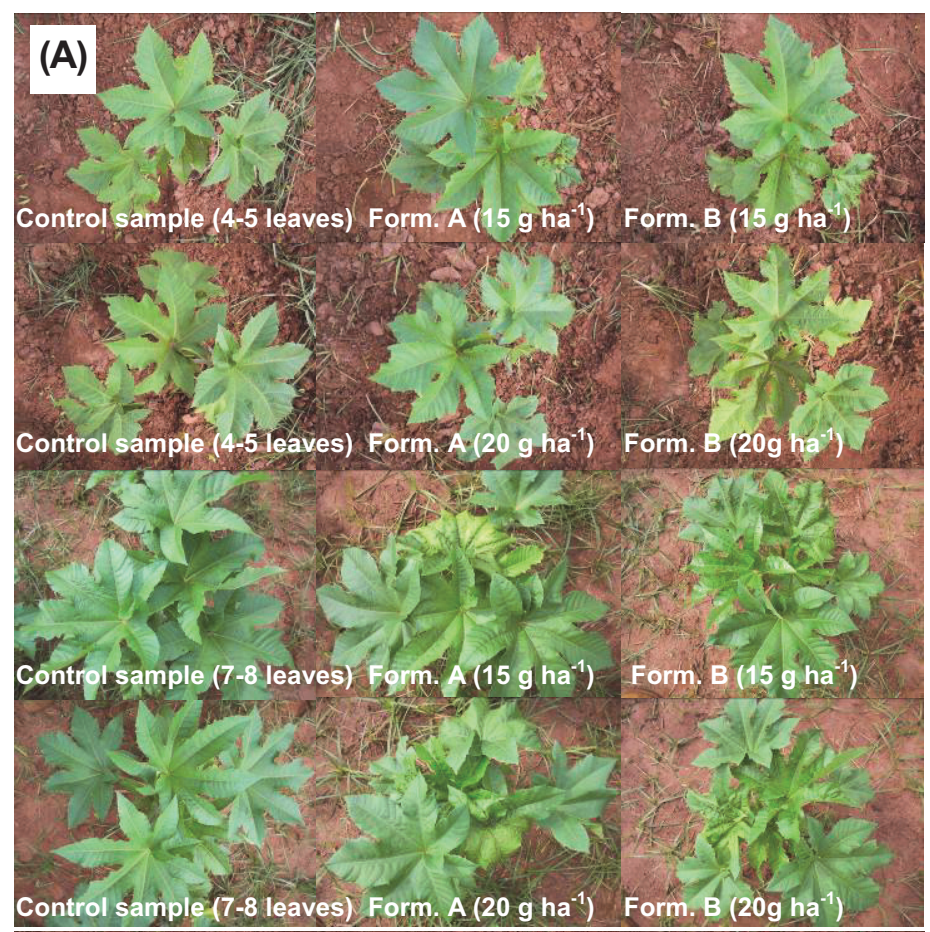

(B)

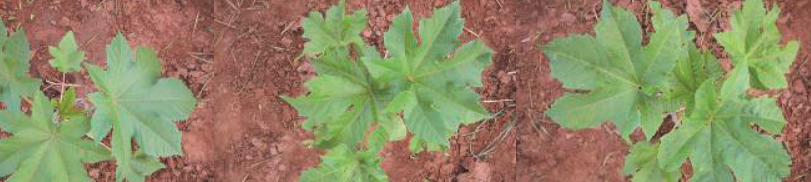

Control sample (4-5 leaves) Form. A (15 $\left.\mathrm{g} \mathrm{ha}^{-1}\right)$ Form. B (15 g hat)

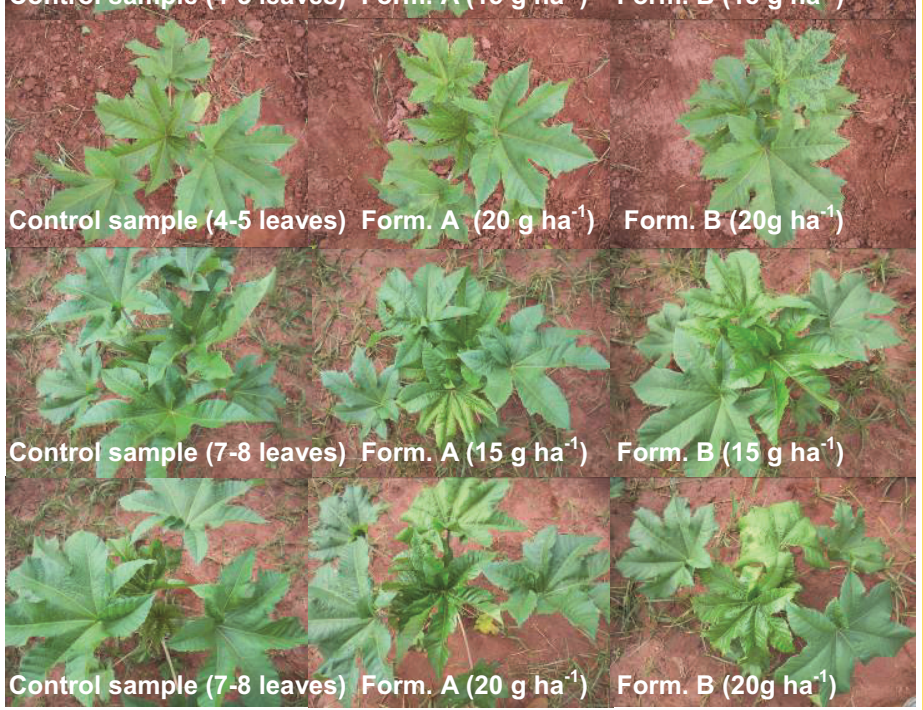

Figure 2 - Visual symptoms of intoxication on day 14 DAA on the hybrids Savana (A) and AL Guarany 2002 (B) submitted to the application in post-emergence of chlorimuron-ethyl in different stages. 
As for the effect of the herbicide over the castorbean intoxication, the highest chlorimuronethyl dose $\left(20 \mathrm{~g} \mathrm{ha}^{-1}\right)$ provided higher injury levels (Tables 1 and 2). With this dose, castorbeans Lyra and Iris presented more pronounced intoxication symptoms, especially for applications performed in the stages from 7 to 8 leaves, with percentages of 75 and $55 \%$ on day 7 DAA, 36 and $16 \%$ on day 14 DAA and 13 and $8 \%$ on day 21 DAA, respectively (average of the values obtained with the two formulations). For the hybrid Savana, the highest intoxication occurred with the $20 \mathrm{~g} \mathrm{ha}^{-1}$ dose in a later application (7 to 8 leaves), reaching 60 and $30 \%$ on day 7 and 14 DAA, respectively. As for the castorbean AL Guarany 2002, in spite of the fact that symptoms were light in the last two evaluations, the $20 \mathrm{~g} \mathrm{ha}^{-1}$ chlorimuron-ethyl dose applied with 7 to 8 leaves also resulted in higher intoxication, constituting average values of 16 and $6 \%$ for the two formulations, on day 14 and 21 DAA, respectively. For what concerns the effect of the formulations starting from the same used dose, only for the Iris hybrid it was possible to observe a higher percentage with the $\mathrm{B}$ formulation on day 21 DAA.

The chlorophyll content on day 7 DAA was reduced by chlorimuron-ethyl in all evaluated genetic materials (Table 3). An exception was verified only for the application performed on castorbean plants with 7 to 8 leaves from the AL Guarany 2002 cultivar. Therefore, these results confirm the higher levels of injuries observed on the hybrids. Still, it is important to highlight that the reduction in the SPAD index was more pronounced in the applications with 4 to 5 leaves, when compared to the results obtained with 7 to 8 leaves. As for the effect of the herbicide treatments, it was only observed that the $20 \mathrm{~g} \mathrm{ha}^{-1}$ chlorimuron-ethyl dose at the 4 to 5 leaves stage resulted in lower chlorophyll contents of the Iris and AL Guarany 2002 castorbeans.

Table 3 - Chlorophyll content (SPAD index) in leaves from the castorbean Lyra, Isis, Savana and AL Guarany 2002 on day 7 DAA by chlorimuron-ethyl in post-emergence

\begin{tabular}{|c|c|c|c|c|c|c|c|c|}
\hline \multirow{3}{*}{ Treatments } & \multicolumn{8}{|c|}{ Chlorophyll content (SPAD index) } \\
\hline & \multicolumn{2}{|c|}{ Lyra } & \multicolumn{2}{|c|}{ Iris } & \multicolumn{2}{|c|}{ Savana } & \multicolumn{2}{|c|}{ AL Guarany 2002} \\
\hline & 4-5 leaves & $7-8$ leaves & 4-5 leaves & 7-8 leaves & 4-5 leaves & 7-8 leaves & 4-5 leaves & $7-8$ leaves \\
\hline Control sample & $66.4 \mathrm{a} \mathrm{A}$ & $51.0 \mathrm{a} \mathrm{B}$ & $66.4 \mathrm{a} \mathrm{A}$ & $51.6 \mathrm{a} \mathrm{B}$ & $67.2 \mathrm{a}$ & $51.6 \mathrm{a}$ & $65.6 \mathrm{a} \mathrm{A}$ & 60.6 a B \\
\hline $\begin{array}{l}\text { Formulation A } \\
\left(15 \mathrm{~g}_{\text {a.i. }} \mathrm{ha}^{-1}\right)\end{array}$ & $27.4 \mathrm{~b} \mathrm{~B}$ & $34.9 \mathrm{~b} \mathrm{~A}$ & $29.0 \mathrm{bc} \mathrm{B}$ & $33.9 \mathrm{~b} \mathrm{~A}$ & $31.3 \mathrm{~b}$ & $33.4 \mathrm{~b}$ & $37.6 \mathrm{bc} \mathrm{B}$ & 55.6 a A \\
\hline $\begin{array}{l}\text { Formulation B } \\
\left(15 \mathrm{~g}_{\text {a.i. }} \mathrm{ha}^{-1}\right)\end{array}$ & $24.0 \mathrm{~b} \mathrm{~B}$ & $38.2 \mathrm{~b} \mathrm{~A}$ & $33.0 \mathrm{~b} \mathrm{~A}$ & $33.3 \mathrm{~b} \mathrm{~A}$ & $30.8 \mathrm{~b}$ & $33.4 \mathrm{~b}$ & $42.0 \mathrm{~b} \mathrm{~B}$ & 55.6 a A \\
\hline $\begin{array}{l}\text { Formulation A } \\
\left(20 \mathrm{~g}^{2} \text { a.i. } \mathrm{ha}^{-1}\right)\end{array}$ & $24.1 \mathrm{~b} \mathrm{~B}$ & $38.1 \mathrm{~b} \mathrm{~A}$ & $24.6 \mathrm{c} \mathrm{B}$ & $34.9 \mathrm{~b} \mathrm{~A}$ & $26.8 \mathrm{~b}$ & $34.1 \mathrm{~b}$ & $32.4 \mathrm{~cd} \mathrm{~B}$ & $55.2 \mathrm{a} \mathrm{A}$ \\
\hline $\begin{array}{l}\text { Formulation B } \\
\left(20 \mathrm{~g}^{2} . \mathrm{i}^{-1} \mathrm{ha}^{-1}\right)\end{array}$ & 24.6 b B & $37.8 \mathrm{~b} \mathrm{~A}$ & $25.6 \mathrm{c} \mathrm{B}$ & $34.4 \mathrm{~b} \mathrm{~A}$ & $25.4 \mathrm{~b}$ & $34.5 \mathrm{~b}$ & $28.0 \mathrm{~d} \mathrm{~B}$ & 54.6 a A \\
\hline $\mathrm{F}_{\text {cal }}$ Herbicides & \multicolumn{2}{|c|}{$170.9^{*}$} & \multicolumn{2}{|c|}{$145.09 *$} & \multicolumn{2}{|c|}{$136.09 *$} & \multicolumn{2}{|c|}{$57.77^{*}$} \\
\hline $\mathrm{F}_{\text {cal }}$ Stages & \multicolumn{2}{|c|}{$62.9^{*}$} & \multicolumn{2}{|c|}{$4.32 *$} & \multicolumn{2}{|c|}{$1.41^{\mathrm{ns}}$} & \multicolumn{2}{|c|}{$231.5^{*}$} \\
\hline $\mathrm{F}_{\text {cal }} \mathrm{H} \times \mathrm{E}$ & \multicolumn{2}{|c|}{$45.09^{*}$} & \multicolumn{2}{|c|}{$23.74 *$} & \multicolumn{2}{|c|}{$20.39^{*}$} & \multicolumn{2}{|c|}{$30.19^{*}$} \\
\hline $\mathrm{VC}(\%)$ & \multicolumn{2}{|c|}{7.27} & \multicolumn{2}{|c|}{8.02} & \multicolumn{2}{|c|}{8.31} & \multicolumn{2}{|c|}{6.51} \\
\hline DMS H & \multicolumn{2}{|c|}{5.51} & \multicolumn{2}{|c|}{6.08} & \multicolumn{2}{|c|}{6.33} & \multicolumn{2}{|c|}{6.55} \\
\hline DMS E & \multicolumn{2}{|c|}{3.87} & \multicolumn{2}{|c|}{4.27} & \multicolumn{2}{|c|}{4.45} & \multicolumn{2}{|c|}{4.60} \\
\hline
\end{tabular}

Averages followed by the same lowercase letter in the column and the same capital letter on the line (within each genetic material) do not statistically differ among themselves by Tukey's test $(\mathrm{p} \leq 0.05) .{ }^{*}$ significant by $\mathrm{F}$ test $(\mathrm{p} \leq 0.05)$; ${ }^{\mathrm{ns}}=$ non significant.

Maciel et al. (2011) observed lower chlorophyll content in leaves from the AL Guarany 2002 cultivar, according to the application of isoxaflutole in post-emergence, supporting the intoxication observed between day 7 and 28 DAA. Therefore, results obtained with this carotenoid synthesis inhibitor herbicide and with chlorimuron-ethyl, which inhibits the ALS enzyme, show that the chlorophyll content may be used as an intoxication indicator in studies about herbicide selectivity in the culture of castorbean.

As for the height of plants, the Iris hybrid presented a growth reduction when submitted to the herbicide in the $20 \mathrm{~g} \mathrm{ha}^{-1}$ dose with the B formulation in the 7 to 8 leave stage (Table 4). 
Table 4 - Height and diameter of the stem from castorbean plants Lyra, Isis, Savana and AL Guarany 2002 on day 40 DAA by chlorimuron-ethyl in post-emergence

\begin{tabular}{|c|c|c|c|c|c|c|c|c|}
\hline \multirow{3}{*}{ Treatments } & \multicolumn{8}{|c|}{ Height $(\mathrm{cm})$} \\
\hline & \multicolumn{2}{|c|}{ Lyra } & \multicolumn{2}{|c|}{ Iris } & \multicolumn{2}{|c|}{ Savana } & \multicolumn{2}{|c|}{ AL Guarany 2002} \\
\hline & 4-5 leaves & $7-8$ leaves & 4-5 leaves & 7-8 leaves & 4-5 leaves & 7-8 leaves & 4-5 leaves & 7-8 leaves \\
\hline Control sample & 99.3 a A & 105.7 a A & 108.8 a A & $105.8 \mathrm{a} \mathrm{A}$ & $103.6 \mathrm{a} \mathrm{A}$ & $88.3 \mathrm{a} \mathrm{B}$ & $84.2 \mathrm{~B}$ & $102.8 \mathrm{~A}$ \\
\hline $\begin{array}{l}\text { Formulation A } \\
\left(15 \mathrm{~g} \text { a.i. } \mathrm{ha}^{-1}\right)\end{array}$ & $108.4 \mathrm{a} \mathrm{A}$ & $95.3 \mathrm{ab} \mathrm{A}$ & $111.3 \mathrm{a} \mathrm{A}$ & $109.3 \mathrm{a} \mathrm{A}$ & $82.1 \mathrm{~b} \mathrm{~A}$ & 94.5 a A & $87.3 \mathrm{~A}$ & $94.1 \mathrm{~A}$ \\
\hline $\begin{array}{l}\text { Formulation B } \\
\left(15 \mathrm{~g} \text { a.i. } \mathrm{ha}^{-1}\right)\end{array}$ & 105.1 a A & $94.3 \mathrm{ab} \mathrm{A}$ & 114.9 a A & 106.9 a A & $90.3 \mathrm{ab} \mathrm{A}$ & 99.3 a $\mathrm{A}$ & $84.3 \mathrm{~A}$ & $101.0 \mathrm{~A}$ \\
\hline $\begin{array}{l}\text { Formulation A } \\
\left(20 \mathrm{~g} \text { a.i. } \mathrm{ha}^{-1}\right)\end{array}$ & 96.9 a A & $85.4 \mathrm{~b} \mathrm{~A}$ & $111.8 \mathrm{a} \mathrm{A}$ & $96.9 \mathrm{ab} B$ & $70.2 \mathrm{~b} \mathrm{~A}$ & 81.5 a A & $79.3 \mathrm{~B}$ & $98.0 \mathrm{~A}$ \\
\hline $\begin{array}{l}\text { Formulation B } \\
\left(20 \mathrm{~g} \mathrm{a.i.}^{-1}\right)\end{array}$ & 90.9 a A & $85.3 \mathrm{~b} \mathrm{~A}$ & $110.5 \mathrm{a} \mathrm{A}$ & 88.9 b B & $72.8 \mathrm{~b} \mathrm{~A}$ & 87.5 a A & $78.4 \mathrm{~B}$ & $96.3 \mathrm{~A}$ \\
\hline $\mathrm{F}_{\text {cal }}$ Herbicides & \multicolumn{2}{|c|}{$4.16^{*}$} & \multicolumn{2}{|c|}{$3.45 *$} & \multicolumn{2}{|c|}{$5.95 *$} & \multicolumn{2}{|c|}{$0.38^{\mathrm{ns}}$} \\
\hline $\mathrm{F}_{\text {cal }}$ Stages & \multicolumn{2}{|c|}{$5.74 *$} & \multicolumn{2}{|c|}{$20.05^{*}$} & \multicolumn{2}{|c|}{$3.90 *$} & \multicolumn{2}{|c|}{$17.34 *$} \\
\hline $\mathrm{F}_{\text {cal }} \mathrm{HxE}$ & \multicolumn{2}{|c|}{$1.51^{\mathrm{NS}}$} & \multicolumn{2}{|c|}{$2.79^{\mathrm{ns}}$} & \multicolumn{2}{|c|}{$2.87^{\text {ns }}$} & \multicolumn{2}{|c|}{$0.36^{\mathrm{ns}}$} \\
\hline $\mathrm{VC}(\%)$ & \multicolumn{2}{|c|}{9.44} & \multicolumn{2}{|c|}{6.58} & \multicolumn{2}{|c|}{11.82} & \multicolumn{2}{|c|}{13.21} \\
\hline DMS H & \multicolumn{2}{|c|}{18.8} & \multicolumn{2}{|c|}{14.47} & \multicolumn{2}{|c|}{21.23} & \multicolumn{2}{|c|}{24.71} \\
\hline \multirow[t]{2}{*}{ DMS E } & \multicolumn{2}{|c|}{13.2} & \multicolumn{2}{|c|}{10.16} & \multicolumn{2}{|c|}{14.92} & \multicolumn{2}{|c|}{17.36} \\
\hline & \multicolumn{8}{|c|}{ Stem diameter $(\mathrm{cm})$} \\
\hline Control sample & $2.4 \mathrm{~A}$ & $2.0 \mathrm{~B}$ & 2.3 & 1.9 & $2.9 \mathrm{a} \mathrm{A}$ & $2.3 \mathrm{a} \mathrm{B}$ & 3.0 & 3.2 \\
\hline $\begin{array}{l}\text { Formulation A } \\
\left(15 \mathrm{~g} \text { a.i. } \mathrm{ha}^{-1}\right)\end{array}$ & $2.4 \mathrm{~A}$ & $2.2 \mathrm{~B}$ & 2.4 & 2.1 & $2.5 \mathrm{ab} \mathrm{A}$ & $2.6 \mathrm{a} \mathrm{A}$ & 3.1 & 2.8 \\
\hline $\begin{array}{l}\text { Formulation B } \\
\left(15 \mathrm{~g} \mathrm{a.i.}^{-1}\right)\end{array}$ & $2.5 \mathrm{~A}$ & $2.0 \mathrm{~B}$ & 2.4 & 2.1 & $2.6 \mathrm{ab} \mathrm{A}$ & $2.6 \mathrm{a} \mathrm{A}$ & 3.0 & 3.3 \\
\hline $\begin{array}{l}\text { Formulation A } \\
\left(20 \mathrm{~g}_{\text {a.i. }} \mathrm{ha}^{-1}\right)\end{array}$ & $2.5 \mathrm{~A}$ & $2.1 \mathrm{~B}$ & 2.4 & 2.1 & $2.5 \mathrm{ab} A$ & $2.2 \mathrm{a} \mathrm{A}$ & 2.9 & 2.8 \\
\hline $\begin{array}{l}\text { Formulation B } \\
\left(20 \mathrm{~g}^{2} \text { a.i. } \mathrm{ha}^{-1}\right)\end{array}$ & $2.3 \mathrm{~A}$ & $1.9 \mathrm{~B}$ & 2.2 & 1.8 & $2.3 \mathrm{~b} \mathrm{~A}$ & $2.2 \mathrm{a} \mathrm{A}$ & 2.9 & 2.8 \\
\hline $\mathrm{F}_{\text {cal }}$ Herbicides & & $56^{\mathrm{ns}}$ & & $9^{\text {ns }}$ & & $9^{*}$ & & $39^{n-5}$ \\
\hline $\mathrm{F}_{\text {cal }}$ Stages & & $01 *$ & & $9^{\text {ns }}$ & & $.2 *$ & & $2^{\text {ns }}$ \\
\hline $\mathrm{F}_{\text {cal }} \mathrm{H} \times \mathrm{E}$ & & $32^{\mathrm{ns}}$ & 0.0 & $2^{\text {ns }}$ & & $.3^{\mathrm{ns}}$ & & $28^{\text {ns }}$ \\
\hline $\mathrm{VC}(\%)$ & & & & & 9 & 05 & 11 & \\
\hline DMS H & & & & & & 46 & & 73 \\
\hline DMS E & & & & & 0 & 33 & & 51 \\
\hline
\end{tabular}

Averages followed by the same lowercase letter in the column and the same capital letter on the line (within each genetic material) do not statistically differ among themselves by Tukey's test $(\mathrm{p} \leq 0.05)$. ${ }^{*}$ significant by $\mathrm{F}$ test $(\mathrm{p} \leq 0.05)$; ${ }^{\mathrm{n}}=$ non significant.

However, for the Savana hybrid, reductions in height occurred with applications in the most precocious stage (4 to 5 leaves), when using the A formulation in the lowest dose of $20 \mathrm{~g} \mathrm{ha}^{-1}$ with both formulations.

As for the stem diameter, there was a growth decrease only for the Savana hybrid in the 4 to 5 leave stage, when applying the $20 \mathrm{~g} \mathrm{ha}^{-1}$ chlorimuron-ethyl dose in the B formulation. Costa et al. (2015) did not observe chlorimuron-ethyl effects $\left(15 \mathrm{~g} \mathrm{ha}^{-1}\right)$ over the height and diameter of the stem form the castorbean cultivar BRS Energia.

For what concerns the grain productivity of castorbean, in the Lyra hybrid there was an average reduction of $42 \%$ with the $20 \mathrm{~g} \mathrm{ha}^{-1}$ chlorimuron-ethyl dose, applied in the 7 to 8 leave stage, regardless of the used formulation, when compared to the control sample (Table 5). For the Savana hybrid, in the same dose with the A formulation, the productivity reduction was $59 \%$, but only for the application performed in the most precocious stage (4 to 5 leaves). For Iris and AL Guarany 2002 castorbeans, it was not possible to verify the productivity decrease due to 
Table 5 - Productivity of the castorbeans Lyra, Isis, Savana and AL Guarany 2002 on day 140 DAA submitted to the application of chlorimuron-ethyl in post-emergence

\begin{tabular}{|c|c|c|c|c|c|c|c|c|}
\hline \multirow{3}{*}{ Treatments } & \multicolumn{8}{|c|}{ Productivity $\left(\mathrm{kg} \mathrm{ha}^{-1}\right)$} \\
\hline & \multicolumn{2}{|c|}{ Lyra } & \multicolumn{2}{|c|}{ Iris } & \multicolumn{2}{|c|}{ Savana } & \multicolumn{2}{|c|}{ AL Guarany 2002} \\
\hline & 4-5 leaves & $7-8$ leaves & 4-5 leaves & $7-8$ leaves & 4-5 leaves & $\begin{array}{c}7-8 \\
\text { leaves }\end{array}$ & 4-5 leaves & $7-8$ leaves \\
\hline Control sample & $2224 \mathrm{ab}$ & $2569 \mathrm{a}$ & $2313 \mathrm{~A}$ & $2065 \mathrm{~A}$ & $1783 \mathrm{a}$ & $1358 \mathrm{a}$ & $1355 \mathrm{~b} \mathrm{~A}$ & $1438 \mathrm{ab} A$ \\
\hline $\begin{array}{l}\text { Formulation } \mathrm{A} \\
\left(15 \mathrm{~g} \text { a.i. } \mathrm{ha}^{-1}\right)\end{array}$ & $2602 \mathrm{a}$ & $2212 \mathrm{ab}$ & $2302 \mathrm{~A}$ & 1948 A & $1191 \mathrm{ab}$ & $1223 \mathrm{a}$ & $1688 a b$ A & $1347 \mathrm{ab} A$ \\
\hline $\begin{array}{l}\text { Formulation B } \\
\left(15 \mathrm{~g} \text { a.i. } \mathrm{ha}^{-1}\right)\end{array}$ & $2104 \mathrm{ab}$ & $2051 a b c$ & $2311 \mathrm{~A}$ & 2448 A & 1559 a & $1537 \mathrm{a}$ & 1970 a A & 1948 a A \\
\hline $\begin{array}{l}\text { Formulation } \mathrm{A} \\
\left(20 \mathrm{~g} \text { a.i. } \mathrm{ha}^{-1}\right)\end{array}$ & $1775 \mathrm{~b}$ & $1422 \mathrm{c}$ & $2207 \mathrm{~A}$ & $1958 \mathrm{~A}$ & $735 \mathrm{~b}$ & $950 \mathrm{a}$ & $1692 \mathrm{ab} A$ & 1203 b B \\
\hline $\begin{array}{l}\text { Formulation B } \\
\left(20 \mathrm{~g} \text { a.i. } \mathrm{ha}^{-1}\right)\end{array}$ & $1856 \mathrm{~b}$ & $1545 \mathrm{bc}$ & $2108 \mathrm{~A}$ & $1778 \mathrm{~B}$ & $1295 \mathrm{ab}$ & 1085 a & 1958 a A & $1634 \mathrm{ab} A$ \\
\hline $\mathrm{F}_{\text {cal }}$ Herbicides & \multicolumn{2}{|c|}{$10.6^{*}$} & \multicolumn{2}{|c|}{$2.37^{\mathrm{ns}}$} & \multicolumn{2}{|c|}{$8.18^{*}$} & \multicolumn{2}{|c|}{$5.56^{*}$} \\
\hline$F_{\text {cal }}$ Stages & \multicolumn{2}{|c|}{$2.14^{\mathrm{ns}}$} & \multicolumn{2}{|c|}{$5.07^{*}$} & \multicolumn{2}{|c|}{$0.77^{\text {ns }}$} & \multicolumn{2}{|c|}{$5.64^{*}$} \\
\hline $\mathrm{F}_{\text {cal }} \mathrm{HxE}$ & \multicolumn{2}{|c|}{$1.75^{\mathrm{ns}}$} & \multicolumn{2}{|c|}{$0.92^{\mathrm{ns}}$} & \multicolumn{2}{|c|}{$1.36^{\mathrm{ns}}$} & \multicolumn{2}{|c|}{$1.35^{\text {ns }}$} \\
\hline $\mathrm{VC}(\%)$ & \multicolumn{2}{|c|}{16.16} & \multicolumn{2}{|c|}{13.67} & \multicolumn{2}{|c|}{23.33} & \multicolumn{2}{|c|}{17.94} \\
\hline DMS H & \multicolumn{2}{|c|}{679.85} & \multicolumn{2}{|c|}{605.45} & \multicolumn{2}{|c|}{612.95} & \multicolumn{2}{|c|}{601.78} \\
\hline DMS E & \multicolumn{2}{|c|}{477.46} & \multicolumn{2}{|c|}{425.21} & \multicolumn{2}{|c|}{430.48} & \multicolumn{2}{|c|}{422.64} \\
\hline
\end{tabular}

Averages followed by the same lowercase letter in the column and the same capital letter on the line (within each genetic material) do not statistically differ among themselves by Tukey's test $(\mathrm{p} \leq 0.05) .{ }^{*}$ significant by $\mathrm{F}$ test $(\mathrm{p} \leq 0.05)$; ${ }^{\text {ns }}=$ non significant.

the application of chlorimuron-ethyl, regardless of the dose and application period. Similarly, Sofiatti et al. (2012) did not verify a reduction in productivity for the BRS Energia castorbean with $15 \mathrm{~g} \mathrm{ha}^{-1}$ of chlorimuron-ethyl.

Costa et al. (2015) also did not verify interference in the castorbean productivity with the association of s-metolachlor + clomazone applied in pre-emergence, combined with the sequential of chlorimuron-ethyl and halosulfuron-methyl in post-emergence. On the other hand, Grichar et al. (2012) observed intoxication and productivity reduction of the castorbean starting from the application of imazapic and imazethapyr (ALS inhibitors).

Starting from a combined analysis of the results, it was verified that initial intoxication symptoms were more pronounced when chlorimuron-ethyl was applied on the 4 to 5 leaves stage, in relation to the one with later applications ( 7 to 8 leaves). Thus, it is important to consider that under field conditions, in case the application of this herbicide occurs in stages that are more prone to initial intoxication and it is associated to the occurrence of another kind of stress or limiting environmental factor, the risks of damages to the culture development and, consequently, its productivity may be higher.

In this sense, applications with lower doses than the one used in this study, considering the minimum registered one $\left(10 \mathrm{~g} \mathrm{ha}^{-1}\right)$ for soybean and citrus plants in other formulations of this herbicide in the MAPA (Brazil, 2016a), may be considered in future studies or to make decisions under cultivation conditions with higher stress risk, as long as information about the effectiveness of the dose for the weed species that are meant to be controlled, are considered as well. It is also important to highlight that, for the results about chlorophyll content, plant height, stem diameter and productivity obtained in this study, this dynamic of the response standard of the culture at the time of the herbicide application did not become evident.

For what concerns the differences observed between herbicide treatments for the evaluated characteristics, it was verified that the $20 \mathrm{~g} \mathrm{ha}^{-1}$ chlorimuron-ethyl dose, in general, was less

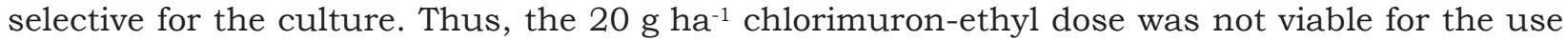
in the culture, starting from the results obtained with three hybrids and one cultivar (Lyra, Iris, Savana and AL Guarany 2002). Works conducted with the BRS Energia cultivar in two regions of 
the Brazilian semiarid, using $15 \mathrm{~g} \mathrm{ha}^{-1}$ of the herbicide, support this statement (Sofiatti et al., 2012; Costa et al., 2015). In this context, it is important to highlight the need to continue the studies, mainly to obtain new information about the selectivity and effectiveness of latifolicide herbicides, aiming at expanding the options that may in the future integrate programs to manage weeds in the castorbean culture.

Thus, starting from the obtained results, it was possible to conclude that the $15 \mathrm{~g} \mathrm{ha}^{-1}$ chlorimuron-ethyl dose was selective to castorbean when applied in the phenological stages of 4 to 5 or 7 to 8 true leaves.

\section{REFERÊNCIAS}

Brasil. Casa Civil. Lei no 9.456 de 25 de abril de 1997. [accessed on: Aug. 12th 2016b] Available at:http://www.planalto.gov.br/ ccivil_03/leis/L9456.htm.

Brasil. Ministério da Agricultura, Pecuária e Abastecimento. Agrofit. [accessed on: Apr. 15th 2016 ] Available at: http:// extranet.agricultura.gov.br/agrofit_cons/principal_agrofit_cons.

Campbell D.N. et al. Developing a castor (Ricinus communis L.) production system in Florida, US: evaluating crop phenology and response to management. Indus Crops Prod. 2014;53:221- 7.

Chagas H.A. et al. Avaliação de fungicidas, óleos essências e agentes biológicos no controle de Amphobotrys ricini em mamoneira (Ricinus communis L.). Summa Phytopathol. 2014;40:42-8.

Companhia Nacional de Abastecimento - CONAB. Mamona série histórica. [acessado em: 28 de abr. de 2016] Disponível em: http://www.conab.gov.br.

Costa A.G.F. et al. Weed management with herbicides applied in pre and postemergence on castor crop. Planta Daninha. 2015;33:551-9.

Costa A.G.F. et al. Weed management strategies for castor bean crops. Acta Sci Agron. 2014;36: 135-45.

Empresa Brasileira de Pesquisa Agropecuária - Embrapa. Sistema brasileiro de classificação de solos. $3^{\text {a }}$. ed. Brasília: 2013. $353 \mathrm{p}$.

Food and Agriculture Oganization of United Nations - FAO. Food and agricultural commodities production. [acessado em: 28 de abril de 2016]. Available at: http://faostat3.fao.org.

Fioreze S.L. et al. Características agronômicas da mamoneira afetadas pelo método de condução de plantas e densidade de semeadura. Ci Agron. 2016;47:86-92.

Grichar W.J., Dotray P.A., Trostle, C.L. Castor (Ricinus communis L.) tolerance to postemergence herbicides and weed control efficacy. Inter J Agron. 2012;2012:1-5.

Hijano N. et al. Seletividade de herbicidas na cultura da alfafa. Planta Daninha. 2013;31:903-18.

Maciel C.D.G. et al. Desenvolvimento de cultivares de mamoneiras em relação à profundidade de semeadura e seletividade de herbicidas dinitroanilinas. Semina: Ci Agr. 2012;33:27-38.

Maciel C.D.G. et al. Seletividade de herbicidas em cultivares de mamona. Rev Bras Oleag Fibr. 2007;11:47-54.

Maciel C.D.G. et al. Seletividade e eficácia de herbicidas inibidores da enzima ACCase na cultura da mamona. Planta Daninha. 2011;29:609-16.

Medeiros K.A.A. et al. Tolerância de mamoneira ao herbicida trifluralin em solos com diferentes texturas. Rev Bras Eng Agríc Amb. 2013;17:1333-9.

Sociedade Brasileira da Ciência das Plantas Daninhas - SBCPD. Procedimentos para instalação, avaliação e análise de experimentos com herbicidas. Londrina: 1995. 42p.

Severino L.S. et al. A review on the challenges for increased production of castor. Agron J. 2012;104:853-80. 
Silva K.C. et al. Tolerância de mamoneira ao herbicida pendimethalin em solos com diferentes capacidades de adsorção. Rev Bras Eng Agríc Amb. 2012;16:1298-304.

Silva R.L.M. et al. Seletividade do halosulfuron-methyl aplicado em pré-emergência da cultura da mamoneira. Rev Bras Eng Agríc Amb. 2015;19:693-7.

Sofiatti V. et al. Pre and postemergence herbicides for weed control in castor crop. Ind Crops Prod. 2012;37:235-7.

Soratto R.S. et al. Espaçamento e população de plantas de mamoneira de porte baixo para colheita mecanizada. Pesq Agropec Bras. 2011;46:245-253. 